\title{
Women running for neighborhood offices in a Turkish city: Motivations and resources for electoral candidacy
}

\author{
Fatma Senol* \\ Izmir Institute of Technology/Department of City and Regional Planning, Mimarlik Fakultesi/ E-Blok Oda: B-08, Guzelbahce Koyu, URLA, 35430 IZMIR/Turkey
}

Keywords:

Citizenship

Female candidacy

Local elections

Neighborhood offices

Muhtar

Turkey

\begin{abstract}
A B S T R A C T
This study is about how gender and local urban scales interact with each other to influence individuals' motivations and resources for political recruitment. The data came from interviews with twenty women who ran for and lost the 2004 local elections for their neighborhood office, muhtarlik, in Eskisehir, Turkey. Considering both individual and institutional factors and the neighborhood scale as important for women's candidacy for local offices, this paper relies on a "relational" view of citizenship while examining the mediating roles of the local scale for citizenship. My findings overall disagreed with the arguments that "women's interests" drive women to enter politics and that the local offices provide more opportunities for women's political recruitment. As women's roles and responsibilities had been changing across multiple spaces, they ran for elections to search for ways to practice their capacities in public arenas. Yet to the electorates, first, even women with high qualities for the office did not appear as the most qualified candidates. Second, most electorates tended to evaluate candidacy qualities in relation to the neighborhood office's weak status in Turkish political system and as an unskilled job. Third, they seemed to associate this "job" positively with men's traditional domestic role as the main breadwinner, consider women's charity and communal works as women's traditional care responsibilities, and to vote mostly for over-middle-aged male incumbents with locally embedded relations. Finally, women missed an opportunity for their candidacy by not transforming their local network-based assets into resources for candidacy.
\end{abstract}

(c) 2009 Elsevier Ltd. All rights reserved.

\section{Introduction}

Sevgi, a female candidate for the elected office of her neighborhood in 2004, evaluated the result of that election: "We lost the election not at but around the ballot box" (original emphasis). She still argues that she was qualified for the office, as she had been always supportive of and well-known by her neighbors, i.e., the voters. Now she thinks that, as much as the "hypocrisy" of her neighbors who promised to but did not vote for her, certain characteristics of the election procedure for this office resulted in her loss.

This case study examines the conditions under which Sevgi and other women, nearly all of whom lost, ran for their neighborhood office in the 2004 local elections of Turkey. It particularly examines how gender and local urban scales interact with each other to influence individuals' motivations and resources for recruiting in urban governance, and relates to the studies about the relationships between citizenship, place, and democracy. Overall, arguing for analyzing these relationships along with the processes that link

\footnotetext{
* Tel.: +90 232 7507069/+90 533 7714446; fax: +90 2327507012.

E-mail address: fatmasenol@iyte.edu.tr
}

economics and politics as experienced locally and differently by individuals and social groups, this paper underlines that citizenship develops via everyday experiences in "place" or locale.

The question of how individuals are recruited in politics, and thus who gets what and under which circumstances has new directions in political geography. "Thinking spatially" about citizenship (McEwan, 2000), certain studies by political and feminist geographers differ from traditional ones by examining the interplays between citizenship and place. They identify and examine the different scales and spaces of citizenship and the abilities of different people to exercise their rights as citizens or even demand for new ones via multiple spaces. They especially re-identify marginal groups' (such as women) abilities and motivations and also the conveniences of local spaces and scales (such as neighborhoods, local organizations, schools, and homes) for improving citizenship rights. Yet most of these studies have been either theoretical or at risk of "homogenizing effect of western understandings" (Secor, 2004: 271) about the marginal groups' opportunities for political recruitment. There is a need for more empirical studies, especially in non-Anglo Saxon contexts, which reexamine the expectations about the engendering of citizenship at local scales via daily experiences shaped by social differences. 
This paper explores the opportunity structures of a group of Turkish women running for elected neighborhood offices. It aims at adding to the understandings about the spatiality of citizenship by re-examining two expectations about how local scale and gender differences affect opportunity structures for political recruitment. The first expectation is that local scales and spaces provide conveniences for better political participation, especially to those excluded traditionally from formal politics (Etzioni, 1993), and for "good" governance based on "active citizenship" (Kearns, 1995). This expectation is revived along with recent practices about neighborhood-based governance and councils across countries, mostly of the west (Fung \& Wright, 2003). It is also enriched by feminist geographers and other studies conceptualizing neighborhoods as the very local and informal grounds for society's distributional and democratic issues and thus for citizenship (Naples et al., 1998). Such potentials of the very locale for marginal groups are explained by the argument that offices at local scales control weaker hierarchies of power relations than at "grand" scales (Phillips, 1995). The second and related expectation associates usually marginal groups' motivations for political involvement with local issues. For women, this argument suggests that their gendered roles and responsibilities in homes and local communities motivate them to become involved in politics. Calling such roles and responsibilities of women as "women's interests," this says that women participate in politics with a distinct group identity based upon their common interests on issues, such as abortion, childcare, or equal opportunities in education and the labor force. It emphasizes establishing "a difference between the interests of women and men" (Phillips, 1995: 68). Yet this expectation might also blur the relationship between common and subjective interests and between gender and other divisions-such as class, ethnicity, race, ideology, and religion - that might override any gendered interest in political recruitment.

Despite these valuable insights, however, both of these expectations about neighborhood scale and women's motivations for political recruitment have been empirically tested almost always only for women in local movements or organizations, or in socalled informal politics, but not for female candidates in formal local politics. How the conditions for women's candidacy evolve at and for the neighborhood scale is an unexamined field that needs feminist geographers' attention. Mostly political scientists examine women's electoral candidacy but with no consideration of the spatial and scale aspects of citizenship.

Using my interviews with female candidates in the 2004 local election in Eskisehir, I examined women's motivations and resources as the opportunity structures for their candidacy. I took the opportunity structures for political participation as a process that goes on within the complexity of actions by diverse subjects "in both the formal politics and spaces of home, neighborhood, workplaces, communities, and media” (Staeheli et al., 2004: 3). I questioned whether and how women's motivations and resources evolve within relation to women's gendered roles and responsibilities and to the election at and for the neighborhood scale: Do their motivations and resources relate to "women's issues" or women's gendered roles and responsibilities at home or neighborhoods? Do women have advantages over men when running for local offices at their neighborhood? Do elections at the neighborhood scale provide more opportunities for women for winning?

Investigation of such questions about the spatiality of citizenship is important for re-identifying the conditions for constructing "good" governance concerned with citizens' fair and equal access to basic opportunities and resources. Yet gender and other differences shape distinct motivations and resources for electoral candidacy, and men more frequently than women seem to acquire the candidacy qualities that are critical for winning elected seats.
Gender disparity in elected offices is documented by the worldwide low percentages of offices taken by women (19.2\% in 2008; IPU, 2008), extending the "gendered political geography" (Staeheli et al., 2004) across regions and countries. For democratic governance, the distinct knowledge, concerns and interest men and women develop through their gendered roles and responsibilities (Bondi \& Peake, 1988) must be represented in formal politics for allocating societal resources (Mansbridge, 1985). Emphasizing that "gender represents a salient, interest-based social cleavage" (Secor, 2004: 267 ), the argument for equal shares of elected seats suggests that women legislators bring perspectives and values on issues that affect women differently than men (Lovenduski, 2001). Still the questions of whether women run for offices because of "women's interests" and whether and what percentages of women in elected office could influence policies related to women's issues (GunesAyata \& Tutuncu, 2008; Lovenduski, 2001) should be subject to more research.

Another of this study's contentions is that choosing a Turkish city as a study site might promise distinct findings about the relationships between citizenship, place and democracy. With historical diversions from world and regional averages about women's presence in politics, Turkey has had percentages of women in elected offices that are much lower than world averages (see Table 1). The percentages of women at local seats (around 1\%) are worse than those at the parliamentary level in Turkey, in contrast to the theoretical expectations and worldwide trends. Elected among and by local dwellers, the officer of each neighborhood (muhtar) assists all units of governments in identifying residents' needs for urban and social services. Also, Turkey is an understudied context about the roles of local scale for political opportunity structures about women's candidacy. Among the studies about party system, election procedures, and ethnic and religious differences in political recruitment (Sayarı \& Esmer et al., 2002), women and womanhood in political party ideologies (Secor, 2001), and women, state, religion and other institutions (Kandiyoti, 1987, 1991; Tekeli, 1995), a few examined women's recruitment in elected offices but only in a historical trajectory (Yaraman, 1999), or at the national and provincial levels (Arat, 1989; Frey, 1965; Gunes-Ayata, 1991; GunesAyata \& Tutuncu, 2008). And studies about traditions of local governance, elections, and elected ones (Incioglu, 2002) examined only "locales" that excluded the neighborhood.

Finally, this paper tells the stories of election losers, rather than of winners as most studies do. In 2005, I interviewed 20 out of 30 female candidates for the office of their neighborhood in 2004 in Eskisehir, a mid-sized Turkish city. All but three of the thirty lost their elections. To investigate their motivations and resources for electoral candidacy, I asked these women about: (a) their candidacy

Table 1

Percentages (\%) of women in parliaments (both houses combined) in the world, world regions and in Turkey between the years of 1997 and 2008.

\begin{tabular}{lcccc}
\hline & 1997 & \multicolumn{1}{c}{2000} & \multicolumn{1}{c}{2004} & 2008 \\
\hline Nordic countries & 35.9 & 38.8 & 40.1 & 41.4 \\
Americas & 13.2 & 16.0 & 18.4 & 20.8 \\
Europe - OSCE member countries including & 13.2 & 15.9 & 18.6 & 20.7 \\
$\quad$ Nordic countries & & & & \\
Europe - OSCE member countries excluding & 9.7 & 15.0 & 16.8 & 19.2 \\
$\quad$ Nordic countries & & & & \\
Asia & 11.5 & 14.1 & 15.0 & 18.2 \\
Sub-Saharan Africa & 11.0 & 12.1 & 14.8 & 17.5 \\
Pacific & 12.7 & 13.6 & 13.2 & 14.9 \\
Arab States & 3.4 & 3.6 & 6.5 & 9.1 \\
WORLD & 11.3 & 13.8 & 15.7 & 18.4 \\
TURKEY & 2.36 & 4.36 & 4.4 & 9.11 \\
\hline
\end{tabular}

Note: Data compiled by the Inter-Parliamentary Union (IPU, 2008), data for years compiled by author. 
qualities and motivations in respect to their gendered roles and responsibilities; (b) familial and local support and constraints for their candidacy; (c) voters' stereotypes about gender roles and qualities for public officers; and (d) voters' and voting procedures' approach to the election for neighborhood offices.

The findings of this study disagree with the two expectations described earlier. Women in this study were motivated for candidacy not necessarily out of "women's interests," but more as a search for areas in which to practice their capacities in public arenas. It was women's changing roles and responsibilities across multiple spaces that triggered this search. Women's resources develop commonly in ways that contrast to the expectation about the local scales' better conveniences for women's recruitment in politics. To the electorates, first, even women with high qualities for the office do not appear as the most qualified candidates. Second, most electorates perceive the neighborhood offices as the weakest and most depreciated status within Turkey's political system and as an unskilled job that only require some literacy skills. Third, they relate such status of neighborhood offices to their evaluation of candidates' qualities. They seem to associate this "job" positively with men's traditional domestic role as the main breadwinner and consider women's charity work and support networks as part of her domestic responsibilities. Thus, the voters ultimately vote mostly for over-middle-aged male incumbents with already locally embedded social and economic relations.

\section{Differing opportunities for political recruitment}

To influence decision-making processes about their daily life, citizens participate in voluntary organizations or other political activities, and vote or run at elections. Yet they do not all have equal access to opportunities for political recruitment. Citizens' differing standings across the webs of power relations based on gender, class, race, ethnicity and other characteristics shape this inequality. This section of the paper outlines how gender and local urban scale influence patterns and opportunities for political recruitment, and introduces my study approach.

\section{Patterns of political participation and women/men}

The studies in political science overall say that citizens' opportunities for political recruitment vary in accordance to resources and skills driven from their gender status, social class, education level, group networks, time available, and occupational, political or public service experiences (Verba, Schlozman, \& Brady, 1995), and that these develop distinctly under the influence of social, institutional and political environments shaped by that society's social norms and expectations about gender roles (Norris \& Inglehart, 2000; Studlar \& McAllister, 1991). Also, these characteristics might have differing importance across countries. For instance, in the general elections of North American and West European countries, candidates with financial resources, high educational and jobs status, political experience, public service, name recognition and supportive networks have advantages (Niven, 1998; Norris \& Lovenduski, 1993). Across countries, women's participation in the paid labor force seems to be a strong determinant of women's presence in elected offices (Studlar \& McAllister, 1991).

Commonly, however, in gaining access to resources and skills for running as electoral candidate, women have fewer opportunities than men do. Randall (1987) categorized the explanations about why women have lower access to candidate qualities into two groups. The first group suggests that women lack the opportunities for developing resources and skills that encourage recruitment in elected offices, such as education, employment, class, and political experience. Within patriarchal relations, social norms and women's situational factors expect women to prioritize traditional roles as mothers and wives and then to work as clerks, secretaries, nurses or teachers, i.e., at jobs with care taking responsibilities. Ultimately, women are socialized into feminine, non-competitive roles and backgrounds that do not accord with public offices, whereas men more frequently engage in activities that foster skills for these offices (Evertzen, 2001; Verba et al., 1995).

The second group argues that cultural attitudes, social structures, and political cultures and systems determine the opportunity structure for electoral candidacy (Niven, 1998; Norris \& Inglehart, 2000). Related to these institutional factors, female candidates might be faced with both limited access to managerial skills and training, leadership roles, female role models or mentors in formal politics and also disproportional societal expectations-such as the view that a woman becoming a politician harms her domestic responsibilities or vice versa. Countries' cultural and economic climates too affect the degree of such limitations and expectations. For instance, egalitarian attitudes towards women in office might be affected negatively by strict religious norms (Evertzen, 2001), and relatively positively in post-industrial societies (Norris \& Inglehart, 2000). Also, even when women improve their credentials according to the "masculine candidate model" (Studlar \& McAllister, 1991), barriers to women's candidacy still emerge due to the "gatekeepers" (e.g., financial supporters, political party leaders and members), the prejudices of many voters against female candidacies (Norris \& Inglehart, 2000), and the depressing influence of male incumbency on women (Schwindt-Bayer, 2005).

In general, both groups of work examined women's opportunity structures for candidacy only at the scale of general elections and overlooked the elections for offices of smaller geographical scales. Thus, this paper relates also to the literature about political recruitment at local scales, as follows.

\section{Neighborhood as the "ideal" scale for political recruitment}

Urban studies consider neighborhoods as important grounds for community building and urban life via neighboring or local organizations. As socio-spatial units, neighborhoods provide social and economic support to dwellers and grounds for political mobilizations about place- or identity-based issues (Abu-Lughod, 1994; Wolch \& Dear, 1989).

Similarly, studies in political science and political geography argue that place-based communities at small scales, rather than solely communities of affiliations, are important for revitalizing democracy for three reasons. First, the immediacy of local community in people's lives provides more generative citizen participation than at the nation-state level (Berry, Portney, \& Thompson, 1993; Kemmis, 1995). Second, local communities know their needs and concerns better than bureaucrats and politicians, which should inform better design and implementation of fair and effective policies (Etzioni, 1993; Fisher \& Kling, 1993). Third, neighborhoods are the base for mobilizing local support networks and organizations outside the electoral politics and for the issues relating to why marginalized groups-especially women-become involved in urban politics (Naples et al., 1998; Staeheli \& Clarke, 1995).

It was emphasized that the shift of decision-making from central government to local communities might create better opportunities for individuals' recruitment in formal politics (Mansbridge, 1985; Walzer, 1983). For instance, involvement in local networks/ organizations regarding the issues and relations of domestic spaces might develop an individual's skills, qualities and resources for political involvement. Also, it is argued that local public offices control weaker hierarchies of power relations than those in national parliaments, and thus provide grounds for higher levels of political recruitment by women (Phillips, 1995). 
However, there is little evidence to test the efficacy of the arguments about the significance of small geographical scales for participatory governance via electoral politics. A few studies identify local governments even with contradictory roles in local elections (Faguet, 2004; Manor, 1999) and in resource distribution (Beall, 2004).

\section{Development of citizenship at local scales: The study approach}

Many empirical works take the complex relations of neighborhood scale, gender and political recruitment in limited ways. Of the researches about gender and elections, most examined either the general elections or limited their concept of the locale to the provincial and municipal levels. Works about women's political recruitment at the neighborhood level explored only involvement in grassroots organizations, not in formal elections. Moreover, some of these arguments, evolved within the realities of post-industrial Anglo-Saxon societies, simply presume the realities of other contexts. In contrast to worldwide trends, for instance, Turkey has lower percentages of women at local than at national offices.

Paying attention to these gaps in the literature, this study considers both individual and institutional factors and also the neighborhood scale as important for women's candidacy for local elected offices. The approach of this paper primarily relies on a "relational" view of citizenship and the mediating roles of the local scale for development of citizenship resources and capacities.

The notion that I call the relational view of citizenship has been developed by feminist and other critical approaches to political geography, along with some communitarian views about the social and cultural dimensions of citizenship. Feminist geographers' reconstruction of the notion of politics and of political realms, agents, scales and issues suggests considering individuals' economic, social and other actual circumstances in evaluating their political recruitment processes. This contrasts to the traditional liberal view that idealizes citizens, with their persona reduced to the basic cognitive competencies and civic impulses, and also considers the public sphere as equally open and accessible to all members of a polity in which individuals have equal rights and access to political power. In contrast to the binary notion of political and apolitical realms, this underlines a relational view of citizenship normatively (Lister, 1997; Marston, 1990; Staeheli et al., 2004) and empirically (Conover, Searing, \& Crewe, 1991; Staeheli, 1996; Verba, 1990). That is, citizenship evolves within the interplay of multiple realms, rather than in the liberal notion of "the" separated public sphere. Individuals' roles and responsibilities across multiple realms, like workplaces and domestic spaces, affect their standing as social and political agents. Women and men experience these realms not as individuals but as members of households and communities and through everyday spatialized experiences across different contexts (Ackelberg, 1988; Kandiyoti, 1991; Milroy \& Wismer, 1994; Secor, 2001; Staeheli et al., 2004). Similarly, overlapping systems of oppression based on gender, race, class, and other social characteristics create barriers to inclusion in citizenship (Hill Collins, 1990; Peake, 1995; Pulido, 1997). In sum, individuals have uneven opportunities for political recruitment, within society's interrelated social, economic, and political structures, and in relation to their social and economic characteristics.

Such uneven opportunities develop differently across locales, as individuals' political recruitment is contingent upon the daily and local power struggles within relation to national and global processes (Marston \& Staeheli, 1994). Contributing to variations in daily social practices, here locales appear as "distinct forms of social organization" (Pred, 1984), at which broader economic and political restructuring processes unfold distinctly (Massey, 1994) and combine uniquely with social, economic, and political relations of smaller spatial scales. These reflect themselves in how individuals or groups develop their social identities and resources distinctly across locales (Massey, 1994; Staeheli \& Clarke, 1995; Wolch \& Dear, 1989).

In political recruitment, the opportunities and barriers women are faced with are parts of the structures of overall power relations shaping their lower status within the society. At local scales, these power structures-basically, patriarchy and capitalism-are mediated by multiple institutions, such as family, community, schools, workplaces, local organizations, neighborhoods, and legal procedures and regulations (Lamphere et al., 1992). Women's own stories about their electoral candidacy might decipher these mediating processes as reified by their daily gendered experiences within class-based and racial divisions. These stories might tell both how these mediating grounds shape men's and women's positions in the web of power relations and their access to resources for electoral candidacy particularly, and also how individuals attempt to influence the conditions for their access to formal politics.

To identify and evaluate such mediation processes for women's access to public seats in a Turkish city (Eskisehir), the following sections describe women's economic and political conditions in Turkey and then explore female candidates' own stories about the phases of the election that they lost.

\section{Women's citizenship and elected local offices in Turkey}

Overall, Turkey is ranked very low with women's political performances (see Table 1). According to one argument, women in Turkey have been "emancipated but not liberated," because the Mediterranean culture, Islamist traditions, and the Kemalist ideology have together kept the basics of male domination since the establishment of the Turkish Republic in 1923 out of the Ottoman Empire (Arat, 1989; Kandiyoti, 1987; Tekeli, 1995). Compared to most countries, Turkey addressed the question of women's emancipation relatively early (1934) and extensively with a series of legal reforms, including women's rights to vote and run for offices. However, rather than stemming from women's movements, the governing elite granted these rights for the goals of modernization (Kandiyoti, 1987); thus, "the question of women's rights was a means rather than an end for the founders" of the Republic (Arat, 1989:46). At the first national election, women obtained $4.5 \%$ of the parliamentary seats, a percentage higher than that that era's democracies and the highest in the country's history until 2007 with $9.1 \%$ (see Table 2).

Why do the percentages of women at elected offices differ across countries and time? As demonstrated in the case of Turkey, legal inclusion is not enough to improve women's representation. Though with less consistency, more socio-economically developed countries tend to have less gender inequality and higher shares of women at elected offices (Matland, 1998; Rule, 1987), along with higher rates of women's literacy, participation in education and the paid labor force, and lower rates of women's unemployment and fertility (Randall, 1987; Studlar \& McAllister, 1991).

Turkey has a relatively low rank with economic variables related to women. In the United Nations Development Programme's (UNDP) human and gender development indices (with variables about life expectancy, politics, employment, health and education), Turkey is respectively 92nd out of 177 and 103rd out of 136 countries in 2004 (UNDP, 2006). Overall, differences in education and in per capita income underline the gender disparity in Turkey, which also varies within the country. In contrast to nearly stable world averages of $40 \%$, women's share in the total labor force in Turkey (excluding informal labor sector and unpaid family work) decreased from $35 \%$ in 1980 to $26 \%$ in 2004 , mostly due to its decline in the rural areas (Anker, Melkas, \& Korten, 2003; World 
Table 2

Women in the Turkish Parliament.

\begin{tabular}{llll}
\hline Election year & $\begin{array}{l}\text { Number of } \\
\text { parliamentarians }\end{array}$ & $\begin{array}{l}\text { Number of female } \\
\text { parliamentarians }\end{array}$ & $\begin{array}{l}\text { Women's Share in total } \\
\text { parliamentary seats }(\%)\end{array}$ \\
\hline 1935 & 395 & 18 & 4.6 \\
1939 & 400 & 15 & 3.8 \\
1943 & 435 & 16 & 3.7 \\
1946 & 455 & 9 & 2.0 \\
1950 & 487 & 3 & 0.6 \\
1954 & 535 & 3 & 0.7 \\
1957 & 610 & 7 & 1.1 \\
1961 & 450 & 3 & 1.1 \\
1965 & 450 & 8 & 1.8 \\
1969 & 450 & 5 & 1.1 \\
1973 & 450 & 6 & 1.3 \\
1983 & 400 & 12 & 3.0 \\
1987 & 450 & 6 & 1.3 \\
1991 & 450 & 8 & 1.8 \\
1995 & 550 & 13 & 2.4 \\
1999 & 550 & 22 & 4.0 \\
2002 & 550 & 24 & 4.4 \\
2007 & 550 & 50 & 9.1 \\
\hline
\end{tabular}

Note: Data compiled by the Inter-Parliamentary Union (IPU, 2008), data for years compiled by author.

Bank, 2008). Interestingly, women's representation in professional jobs in Turkey (33.9\%) was higher than world averages in 2000s (28.1\%) (Anker et al., 2003; Sancar-Usur, 2003), probably related to the class-biases of the early republican reforms (Oncu, 1995).

Media images and the influences of religious and social norms support the patriarchal climate and authority structures in Turkey. The husband is accepted as the ultimate authority in the family (Sancar-Usur, 2003; Yaraman, 1999). The political climate with its legal apparatus, party policies, and women's movements has provided some but not enough improvements for the advancement of the national machinery for women's equal participation in decision-making. In the state's policies, there is no gender quota. A concrete step was the establishment of the General Directorate on the Status of Women in 1990, which is still often considered a marginal governmental body. A few parties established gender quotas during the 1990s, which did not improve women's presence in the parliament, because parties tend to place men in the higher ranks of their candidacy lists (Arat, 1989; Gunes-Ayata \& Tutuncu, 2008), and women's branches have had limited effects in promoting female candidacy (Gunes-Ayata \& Tutuncu, 2008).

The women's movement has only slightly affected women's representation in Turkish politics. Women's organizations in the 19th and early 20th centuries focused on the traditional-religious and modern-Westernized forces of the Turkish society (Kandiyoti, 1987). After the 1980 military coup, feminist groups gained partial victories on issues, such as domestic violence and gender-sensitive legislation, and facilitated processes for building women's shelters, consulting for women's human rights, and so on. The movement was influential in the adoption of the New Civil Code and the amendments of the Penal Code during the 2000s that added the articles on gender equality (Gunes-Ayata \& Tutuncu, 2008). Since the 1990s, however, with components of Islamist, Kemalist, leftist and Kurdist characteristics, the movement has often diverged on the diagnosis and solutions of problems (Sancar-Usur, 2003; Yaraman, 1999).

In Turkey, the low rate of women's representation at local governing units (around 1\%) is worse than in parliamentary seats, in contrast to theoretical expectations about local offices' potentials for political participation by marginal groups. This low share at local seats is neither periodical nor local in Turkey. Rather than being an unequal representation, this reflects the "syndrome of absence" of women at local offices (Tekeli, 1995: 17), for which the literature suggests three reasons. Women and womanhood have especially held only symbolic meanings in the Turkish Republic's modernization and nation building projects (Kandiyoti, 1987; Tekeli, 1995). Also, women in Turkey have a lower degree of social mobility and political representation in the communities with 100,000 people or less, and thus with relatively more dominant patriarchal rules (Citci, 2001). Additionally, women's movements and organizations have neglected "the local scale," taking women's issues as related only to national policies. Similarly, women's local organizations have focused more on families' economic needs, rather than on women's political representation (Sancar-Usur, 2003).

Of course, these reasons are not exhaustive or directly relevant to neighborhood offices. Also, the statistics about women at local seats include only those for provincial and municipal governments. No aggregate data is available on elected officers (muhtars) and council members of neighborhoods and of village administrations - the smallest and most traditional local government unit in Turkey (see Tables 3 \& 4). The list of muhtars on the websites of the three largest metropolitan cities (Istanbul, Ankara, and Izmir) suggests $10 \%$ or lower shares of neighborhood seats by women. The next part of this paper hopes to highlight some of the reasons for women's lower shares at neighborhood seats.

\section{Study data and findings}

As the study site, I chose the city of Eskisehir because in 2004 nearly all female candidates for neighborhood seats of this city lost the election and, conveniently, my work-base was there. To become the officer of their neighborhood (headman or muhtar), 30 women and around 200 men out of all 52 neighborhoods ran as candidates in Eskisehir in 2004. Besides certain individual motivations, a woman's organization (KA-DER) encouraged some of these women's candidacy. KA-DER, The Association for the Support and Training of Women Candidates, has been campaigning for women's entry into the formal politics of Turkey since 1997. In 2004 local elections, its branches in five cities-including Eskisehir-provided the female candidates for local seats with lectures about gender differences, public offices, and oral and body languages in public.

Eskisehir is a mid-size city with an urban population of 600,000 . With an economy based on industry, agriculture, and university, this city is ranked at 6 th among 81 provinces. Typical to Turkey's western regions with better socio-economic indicators, Eskisehir's rate of female high school or university graduates is at national averages. With a major shift from the agricultural to the service sector between 1980 and 2000, women's share in Eskisehir's total labor force is near to national averages. Of women, the age cohort of 20-29 has the highest participation rate in the labor force, with most dropouts occurring after marriage around the age of 25 (OGU-Tekam, 2004).

Table 3

Elected seats at the local level in Turkey (2007).

\begin{tabular}{|c|c|c|c|}
\hline Types of local units & $\begin{array}{l}\text { Number } \\
\text { of units }\end{array}$ & Elected bodies & $\begin{array}{l}\text { Appointed } \\
\text { bodies }\end{array}$ \\
\hline Provincial government & 81 & Council & Governor \\
\hline Metropolitan municipality & 16 & $\begin{array}{l}\text { Mayor \& Council } \\
\text { Members }\end{array}$ & $N A$ \\
\hline $\begin{array}{l}\text { Municipality (excluding } \\
\text { metropolitan } \\
\text { municipalities) }\end{array}$ & 3209 & $\begin{array}{l}\text { Mayor \& Council } \\
\text { Members }\end{array}$ & $N A$ \\
\hline Village administration (rural) & ca. 35.000 & $\begin{array}{l}\text { Muhtar \& Council } \\
\text { Members }\end{array}$ & $N A$ \\
\hline Neighborhood offices (urban) & ca. 20.000 & $\begin{array}{l}\text { Muhtar \& Council } \\
\text { Members }\end{array}$ & $N A$ \\
\hline
\end{tabular}

Source: Ministry of Interior, General Directorate of the Local Administration (http:// www.mahalli-idareler.gov.tr/Mahalli/Istatistik.aspx). 
Table 4

Women's share in provincial and municipal elected seats across Turkey and in Eskisehir (1999 and 2004).

\begin{tabular}{|c|c|c|c|c|c|c|c|c|c|}
\hline & \multicolumn{3}{|c|}{ Total number of related seats } & \multicolumn{3}{|c|}{ Number of seats hold by women } & \multicolumn{3}{|c|}{ Women's share in total related seats (\%) } \\
\hline & 1999 Turkey & 2004 Turkey & 2004 Eskisehir & 1999 Turkey & 2004 Turkey & 2004 Eskisehir & 1999 Turkey & 2004 Turkey & 2004 Eskisehir \\
\hline Mayor & 3225 & 3215 & 17 & 18 & 18 & - & 0.56 & 0.56 & 0 \\
\hline Members at municipal councils & 34,477 & 34,084 & 68 & 817 & 541 & 11 & 2.37 & 1.59 & 16.2 \\
\hline Members at provincial councils & 3208 & 3122 & 34 & 57 & 44 & - & 1.78 & 1.41 & 0 \\
\hline
\end{tabular}

Source: Ministry of Interior, General Directorate of the Local Administration (http://www.mahalli-idareler.gov.tr/Mahalli/Istatistik.aspx).

Only on the central municipalities' councils is women's share of elected offices higher than national averages (see Table 4).

In late 2005, with the help of the KA-DER in Eskisehir, I got in touch with and interviewed 20 of 28 female candidates that KADER either contacted or also trained for the election. All taperecorded, these interviews lasted around an hour. The interview themes examined women's own stories about their candidacy in three phases: (a) eligibility-individual qualities and motivations these women had for candidacy in respect to their roles and responsibilities across various realms; (b) selection-spousal, familial and local support and constraint they had; and (c) election-voters' stereotypes about both gender roles and qualifications for public offices, and voters' and voting procedures' consideration of the election for neighborhood offices.

I examined these women's stories to detail how certain institutions, processes, and urban scales mediated these women's daily gendered experiences within class and racial divisions, and thus their access to resources for electoral candidacy. I also questioned how they attempted to influence the conditions for their access to formal politics. The following section introduces my study findings in a comparison to those of Arat (1989) and Gunes-Ayata (1991), the only available works about female officers in Turkey, but which focused respectively on the parliament and a municipal council-that is, female "winners" of the offices at "grand" scales.

This comparison has its own limitations but also interesting insights, mainly due to the neighborhood offices' distinctions from other offices in Turkey. Each neighborhood and village in Turkey has an officer (muhtar) and council members elected among and by that neighborhood's dwellers. Candidates for this office must run independently of any political party. Formed during the Ottoman period, neighborhood offices are the central government's smallest unit in the provinces and have geographical boundaries with around 300 to 1000 dwellings, according to their legal status since 1944. Yet they are not a governing unit. Muhtars practically assist central, provincial and mostly municipal governments in identifying residents' needs for urban services. But they have no vote on provincial and municipal councils, or any staff or budget. They only get a monthly allowance, less than the minimum wage, in addition to fees from residents for processing paperwork.

\section{"Discovering own capacities for public arenas:" Motivations and qualities for candidacy}

Literate Turkish citizens over 25 years old are eligible to run for the office of their neighborhood, if they have been living there for six months or more. Yet what qualities put some candidates over others in this election? With what qualities and motivations did the women in Eskisehir run at elections and how did their qualities influence their motivations for the seat?

It is common knowledge that muhtars are typically over-middleaged male retirees or local merchants. For the typical muhtar, it was not the gender but the educational and occupational characteristics that differed from those of other elected political elites of Turkey. Parliamentarians are usually adult males with university educations with claims to an intellectual and official occupational status and a well-known social status in their provincial community. Since the 1960s party workers have also been elected (Arat, 1989; Frey, 1965). Mostly teachers and lawyers, female parliamentarians generally have educational and occupational statuses much better than those of the typical women in Turkey. By the 1980s (Arat, 1989 ) these characteristics were almost equal to and in the $2000 \mathrm{~s}$ even better than those of male parliamentarians (Gunes-Ayata \& Tutuncu, 2008). In the municipalities and provinces, male elected officers have a socio-economic status lower than that of parliamentarians but higher than those of the average voters, especially in their levels of education. They have usually been affluent local farmers and merchants (Citci, 2001), especially since the 1980s when urban land and services became an important source of local revenues in Turkey. Female elected officers-for instance, in Istanbul between 1960 and 1977-were mostly housewives, with an educational and occupational status lower than that of parliamentarians and equal to typical women in Turkey (Arat, 1989).

These studies create an expectation that in Turkey only the women with educational and occupational credentials similar to or better than of men survived the competition for elected offices. However, the current study's findings about the female candidates and incumbents of neighborhood offices in Eskisehir differed from this conclusion. It was found that the female "losers" all had an educational and in some cases an occupational status similar to those of the male "winners" of neighborhood offices and of the typical women in Turkey. My survey results about Eskisehir's muhtars in 2005 confirmed the typical profile of muhtars. Nearly all male (49 out of 52), these incumbents were either local merchants or retirees from the manufacturing or public sector, and only less than half of them had a high school or university degree (see Table 5). Their time of residency in their neighborhood did not differ from those of female candidates.

At the time of their candidacy, most female candidates were in their early 40s, younger than most incumbents with an average age of 58 in 2005 and of 46 when first elected to the office. When they decided to run for office in their 40s, had these women's roles and responsibilities already been changing across public and private realms, and if so, how? An analysis around this question might reconstruct these women's life stages then and investigate their motivations and qualities for candidacy. This also suggests not presuming any "women's interests" as a priori, but understanding gendered interests as a part of the interplays within the web of social divisions as practiced in everyday life.

My examination of female candidates' charity and paid work experiences and their family's financial status suggested that different groups of women had distinct motivations and candidacy qualities-such as office and communication skills, and support networks with a different basis. While most female candidates had grown-up children and all but three were married, they appeared to be divided into three groups: "Charity Workers," "New Retirees," and "Job Seekers." The Charity Workers, (10 out of 20), had already been doing charity work by themselves or as a member of an organization, and/or participating in a political party for more than 10 years, and some also had family members involved in formal politics. The majority of these women quit their job in their early 20 s when 
Table 5

Comparison of some characteristics between male incumbents (M) and female candidates (F) in 2005, Eskisehir, Turkey.

\begin{tabular}{|c|c|c|c|c|c|c|c|c|c|c|c|c|c|c|}
\hline $\begin{array}{l}\text { Age at election } \\
2004\end{array}$ & $\mathrm{M}$ & $\mathrm{F}$ & $\begin{array}{l}\text { Education } \\
\text { level }\end{array}$ & M & $\mathrm{F}$ & $\begin{array}{l}\text { Any job just } \\
\text { before election? }\end{array}$ & $\mathrm{M}$ & $\mathrm{F}$ & $\begin{array}{l}\text { Kind of jobs before } \\
\text { candidacy? }\end{array}$ & M & $\mathrm{F}$ & $\begin{array}{l}\text { Kind of job in } \\
\text { post-election }\end{array}$ & $\mathrm{M}$ & $\mathrm{F}$ \\
\hline \multirow[t]{2}{*}{$31-40$} & 3 & 5 & primary & 13 & 5 & retired & 37 & 3 & never worked & - & 5 & no other job & 41 & 6 \\
\hline & & & & & & service jobs & - & 4 & service jobs & 4 & 10 & service jobs & 1 & 4 \\
\hline $41-45$ & 4 & 7 & secondary & 19 & 4 & at own local family store & 9 & 4 & at local family store & 9 & 5 & local family store & 9 & 4 \\
\hline $46-50$ & 4 & 8 & high school & 12 & 11 & retired \& a new job & 2 & 1 & managerial / professional & 11 & 4 & managerial professional & 1 & 2 \\
\hline $51-60$ & 20 & - & university & 5 & - & manufacturing & 1 & - & manufacturing & 24 & 2 & & & \\
\hline $61-70$ & 13 & - & & & & no job & - & 8 & Farming & 1 & - & & & \\
\hline $71-80$ & 4 & - & & & & & & & & & & & & \\
\hline $80+$ & 1 & - & & & & & & & & & & & & \\
\hline
\end{tabular}

newly married, which seems usual in this city (OGU-Tekam, 2004). The New Retirees, ( 4 out of 20), had been involved in charity organizations only since their first years of retirement and prior to their candidacy. Most retired as a public employee in their 40s, based on a law passed in the late-1990s. The Job Seekers, (6 out of 20), had either never been employed, or had worked on-and-off at unskilled jobs in the service sector or in their family businesses. They had never been involved in charity work. The majority have had financial problems in the family since the late 1990s and early 2000s due to the national economic crises. In sum, more than the Job Seekers and more or less similarly to those of most incumbents, the New Retirees and Charity Workers seemed to have office and communication skills and also charity- and job-based networks.

How female candidates internalized these conditions of their life then appeared in the ways they explained the importance of their candidacy for that stage of their life. Overall, all groups of women considered this office as a paid job and as an official-thus stronger-tool for improving neighborhood life and representing "voiceless" residents in urban politics. For the Charity Workers, this office was also a base for doing charity work more efficiently using governmental resources. All of the women, especially the Charity Workers, depicted their candidacy as "the project" to discover their own capacities in public arenas. For instance, Sacide thought of her candidacy as an unavoidable stage in her life cycle after long years of her care responsibilities:

We, the housewives, couldn't live for ourselves but for our children, husband, mother-in-law, and so on. Only after 35, we became aware of ourselves. Now we have a considerable amount of life experience and self-esteem; and want to share all these with others and do something.

Carrying this project at their middle ages is a challenge for all groups of women, because the dominant family and marriage patterns in Turkey expect middle-aged women to be already and primarily wives and mothers, and also to quit their jobs after getting married when male breadwinners can support the family. Outside the home, charity work seems to be most suitable for wives and mothers, since this type of work generally takes place in their neighborhood or their children's schools. Yet neither these roles nor charity works necessarily contributed to women's public visibility (Sancar-Usur, 2003). For their public visibility, the Charity Workers aimed at electoral candidacy only after they had developed a manageable routine as mothers and wives and then as charity workers.

"Public visibility" had a different notion for the Job Seekers, such as Sevgi. Her candidacy was her last chance to "stand on her own feet" and support her family financially. Sevgi regrets:

When I was younger and had chances for leaving kids with my mom, I could have found a job. I shouldn't have relied on my husband's job. I wish I had a job to stand on my own feet. The office of muhtar is a career to do so.
Like Sevgi, some Job Seekers have felt the responsibility for keeping their family's economic stability on their shoulders, since their husbands lost their jobs during the late 1990s. Other Job Seekers, especially those with temporary service jobs, needed a job for additional family income and pension payments. According to all Job Seekers, the election provided them with an application for a job that was "appropriate especially to a woman at (their) age and with limited job experiences."

The New Retirees, mostly teachers and secretaries, became candidates out of their search for a new career to "avoid feeling depressed with house chores" after their retirement and especially as a base from which to later run for municipal offices. For this "political career," they felt encouraged by KA-DER's recruitment of (especially recently retired and skilled) women for candidacy. They were assured that their job history would provide them with enough skills and qualities for a political career. Besides, starting with this career via an office in neighborhood would be convenient for newly retired women, whose husbands were now demanding their wives spend "more family time" at home.

Each female candidate still believed that she could be a "good muhtar," whereas most candidates thought that any literate individual with some office but absolutely certain communication skills could be a "good muhtar." The required communication skills for this seat include being able to listen to female dwellers and seniors patiently and kindly, making home visits to (mostly female) residents to follow up on problems, and working with officials patiently and persistently. Some candidates argued that women mostly develop these skills as part of their daily roles and responsibilities, whereas male muhtars do not have patience with the female residents' complaints and are also "too proud" to follow up on paperwork at other governmental offices. Sevil says that women are more persistent at such follow-ups:

Women are not ashamed of asking for help, as this is for our neighborhood. In public offices, when we are told to come back later, we don't get frustrated; we go back there tomorrow. But men say, "I'll go back there sometime later."

Many (especially the New Retirees and the Charity Workers), however, added that a good muhtar must also have a respectable public outlook and manners, and perform as an honest, fair and hard-working public servant, and that being a woman did not guarantee these qualities. They suggested that most of the Job Seekers were not qualified for the office and accused them of mostly pursuing the office solely as a job, rather than as a seat for public service, and not caring about their public outfits and manners as "respectable woman."

Domestic gatekeepers: Patriarchal and "Neighborly" expectations from women's candidacy

Their own qualities and motivations triggered these women's decision to become candidates. Yet in this path, they also needed to 
face certain domestic gatekeepers: male members of women's extended family, nearby neighbors and local voters. These gatekeepers' perception of woman's roles - rather than those of "good muhtars" or candidates' qualities per se-and the importance of neighborhood offices and electoral voting influenced female candidates' chances.

In Turkey, a woman's husband, male relatives, and some social/ political actors control and hold back their social and political activities, because typically any role for woman that does not respect her primary role as wife and mother is perceived to be destructive of family life (Sancar-Usur, 2003). Studies show that for their candidacy decision, most female parliamentarians in Turkey did not have any opposition from their relatives or friends, while still structuring their lives to meet the responsibilities of a traditional housewife. Interestingly, their fathers and husbands sparked the majority of female parliamentarians' decision to enter politics, which was sometimes on the behalf of these men (Gunes-Ayata, 1991). This happened less commonly for female officers at the municipal level (Arat, 1989).

Women in the 2004 election in Eskisehir generally had this authoritative male backing for their candidacy only after getting their husband's and also in some cases their father or brothers' permission. More reluctant than those of the other candidates, it was mostly the male relatives of the New Retirees who preferred that these women stayed at home "peacefully" as new retirees. Each husband put the condition of keeping his domestic life and responsibilities unchanged after the election.

Support from the patriarchs in their family was necessary for women's running, winning, and performing at the office. Yet some candidates argued for the necessity of spousal-rather than any kind of familial-support; in other words, for the female candidates having been married. Kadriye thinks that single or divorced female candidates could not win:

To be a (female) muhtar, you must have a regular family life with a husband supportive of you, regardless of his qualifications. It doesn't work only with a father or brother.

Only when they had secured their male backing, did all groups of women announce their candidacy. KA-DER provided these women with lectures about public offices and gender differences. Most candidates, differently from the more economically secure female parliamentarians of Turkey (Arat, 1989), needed financial support for their relatively less expensive campaign. Some candidates hoped to get KA-DER's financial support, but could not.

Their door-to-door campaigns in their neighborhood challenged female candidates in different ways. It was especially female voters that resisted the idea of women becoming muhtars. They argued that a woman must take care of her family for 24 hours a day, not strangers; that a female muhtar might ignore her job responsibilities if the workload at home became excessive; and simply that muhtars should be "old males," and thus, "wise." Against these stereotypes, Munevver points out the experience gained by women's daily domestic responsibilities in praising women's qualities for offices:

Man is impatient; he needs to sleep and eat very regularly. But woman can stay hungry and sleepless to perform her responsibilities, because she can compromise and be unselfish and caring.

Yet this evaluation was difficult to prove to the electorate, for nearly all of the women were first-time candidates. Prior the 2004 election only 1 out of 52 incumbents was a woman. Rerunning incumbents were already raising this challenge for women, detailed later. Additionally, some neighborhoods had several female candidates, who competed against each other. This diverted the votes for women and weakened women's campaign strategies directed at focusing on the advantages of working with female muhtars.

Another challenge was residents' apathy for voting and recognizing the muhtar's role in improving neighborhood quality, which happened more commonly in poor neighborhoods, regardless of the duration of residency and the neighborhood's location in the city. As the first time candidates, women in such neighborhoods struggled with how to encourage residents to vote. Also, in return for their vote some residents asked for a job or financial assistance. Candidates related such "unrealistic expectations from a muhtar candidate" to all electoral campaigns, in which material benefits are given out. They argued that after witnessing such tactics, voters came to either distrust voting and elected officials, or voted for those who engaged in such practices.

\section{Incumbents' locally embedded relations and electoral procedures}

Just after the voting, Sevgi accused the re-running incumbent for "cheating" at the ballot table. She describes that controversy:

He said, "Sister; there will be of course tricks here because anything goes (around ballot boxes). Don't blame me for you don't know any tricks." I was blamed for not knowing how to cheat! ... Only if it was a democratic election, I would win for sure.

It was mostly on and after election day, not earlier, that female candidates felt disappointed with the whole election process. They especially thought that their lack of experience with the on-site practices during elections was the trigger for their loss. As for the reasons for why they lost, they defined two related issues: incumbents' re-running and the voting arrangements for neighborhood offices. Most candidates took these issues as a reflection of the fact that the Turkish political and electoral system undermines neighborhood offices.

The first issue related to the lack of consecutive term limits for neighborhood offices, which provides incumbents with significant advantages over other candidates. In 2005, half of all muhtars in Eskisehir had been in the office for from 3 to 8 terms, or 15 to 40 years. According to the interviewees, most residents, who visited neighborhood offices usually for paperwork, tended to keep their "old habits" and to vote for "the muhtar they have known for years." The emergence of several new candidates in some neighborhoods supported this tendency among residents. Some interviewers even suspected that the incumbents, knowing this tendency among voters, encouraged friends to run to raise the number of new ("inexperienced") candidates and, thus improve their own chances at elections. They also added that some residents voted for incumbents believing that "old men are wiser" and also that the old incumbents were breadwinners who could not find another job if they lost the election. Another advantage of rerunning incumbents was to use and sometimes abuse governmental resources for their campaign. These resources include the allocation of governmental aids (such as food and coal) and civic donations among poor dwellers, for which muhtars were responsible until recently, and that some incumbents were using this to prioritize their voters. Another resource was the list of registered voters in the neighborhood, which was already available to each incumbent for their routine office work, but not to the candidates. Using this list, each candidate could save considerable campaigning time and effort.

The second issue was about the electoral procedures, some of which are specific to the election for neighborhood offices. Although these procedures might endanger the integrity of a democratic election, their persistence tells candidates (and possibly also the voters) that the Turkish political system undermines the election for neighborhood offices. One of the problems is that the deadline for candidates' declaration of their candidacy was election 
eve, rather than a month before as it is for other offices. Used mostly by incumbents, the last-day declarations harmed participants' perception of democratic campaigning. Another problem related to the fact that there were piles of ballots on polling tables for each candidate. For this election each candidate must prepare their and the council members' ballots. For other offices, the central government provides a single ballot with all of the parties' emblems. In neighborhoods with multiple candidates, clerks at polling tables might have had difficulty in keeping these multiple piles of ballots safe. Missing piles of ballots were not unheard of. Also, either to avoid such problems or to secure votes for themselves, experienced candidates often gave voters their ballots outside the polling stations, which is illegal.

\section{Conclusion}

This study aimed at highlighting certain aspects of how local urban scale and gender differences interact with each other to shape the conditions for women's recruitment in formal politics. It drove its primary data from the stories of female candidates-nearly all of whom lost-about the election for neighborhood offices in Eskisehir (Turkey) in 2004.

My study findings suggest that of women's motivations and resources, some were gender-based and all were related to the changes in economic and social relations embedded in gendered roles at the neighborhood scale and its elected offices. Overall, these findings disagreed with the arguments that "women's interests" drove women to enter formal politics and that the offices at the local scales provided more opportunities for women's recruitment in formal politics.

The motivations of female candidates that were related to their domestic, charity and political work, and the desire of some for jobs did not seem to impress the voters. In exploring the candidates' life stages, this study showed that women got motivated for candidacy primarily out of their search for ways to practice their capacities in public arenas. The conditions that triggered their search varied among groups of female candidates, whereas not all were essentially related to the "women's interests" that emphasized "a difference between the interests of women and men" (Phillips, 1995: 68). In this study, during and by their either retirement, charity work or family's recent financial crisis, these women were motivated by searching for a career in the either or both the political and economic arenas. As a social and geographical part of domestic space, the neighborhood office appeared to female candidates as an "easy" beginning for this search and also as a career that was "appropriate for women at their age." In the election campaign, nearly all female candidates emphasized neighborhood problems related to urban infrastructure, cleanliness, and services, similarly to some male candidates. Meanwhile, to mobilize votes for them, most female candidates counted too much on their neighbors remembering their good neighborly relations, assistance to the needy or other charity works. Yet the election results showed that women's charity work was accepted as part of the "social" but not "political" realm (Sancar-Usur, 2003), and as a reflection of their "natural" care responsibilities for keeping family and neighborhood life intact.

The qualities and resources these women had for their candidacy varied among them, yet there appeared three common features. First, even those women with the better qualities for the seats still did not appear as the most qualified candidate to the electorates, as suggested by the literature (Studlar \& McAllister, 1991). Important for neighborhood offices, candidates' office and communication skills were derived from their socio-economic characteristics - that is, educational, occupational and economic status, and charity and political work experiences. The degree and kind of such characteristics differed among groups of women, as they did for male incumbents in this city. Also, compared to those of female elected officers in Turkey (Arat, 1989; Gunes-Ayata, 1991), these characteristics of female candidates were less developed and represented more of the typical women in Turkey. To run at elections, similarly, all female candidates received male backing in their extended family with the condition for keeping their traditional housewife roles. Yet even for those women with competitive roles and backgrounds in professional jobs and charity works that accorded with the requirements for public offices (especially the New Retirees and the Charity Workers), these skills and qualities did not seem to play any prominent role in neighborhood elections.

Secondly, most electorates appeared to evaluate women and men's candidacy qualities especially in relation to the neighborhood office's weak status within Turkey's political and economic power structure. The majority tended to consider this very local office only as a job for those with some literacy skills. This perception was mostly because muhtars have no legal authority or vote in any formal decision-making process, but only a long list of responsibilities, especially for paperwork, which reduces these offices' potentials as local forums for representative democracy. Another indication of this office's institutionalized depreciation was the difference between electoral procedures for neighborhood offices and for other offices. The former procedure operated in a way that undermined the neighborhood office in the political realm. For instance, the recruitment arrangements often favored incumbents over inexperienced candidates. Additionally, the fact that candidates for neighborhood offices must run independently from political parties perpetuated this office's isolation from the resources of formal politics. This rule might seem to have encouraged the electorates of neighborhood offices to vote, at least in principle, on the basis of candidates' characteristics and qualities-rather than for their parties, which happens often at municipal elections. However, while such distinct legal and electoral rules among elected offices created a boundary between formal/ "grand"/national politics versus informal/ "small"/very local politics, the neighborhood office's status is the weakest at this ranking of Turkish political system and electorates' perception.

In relation to such categorization of elected offices, third, voters seemed to categorize candidates' gender roles and responsibilities, to prioritize traditional domestic roles and then, to vote mostly for over-middle-aged male incumbents, according to the interviewees. For the job as a muhtar, the latter categorization related primarily to man's traditional role as the breadwinner of the family, rather than solely to woman's domestic care responsibilities. In other words, the perception was that to keep the family and neighborhood life intact, the man must have a job, whereas a woman can perform her caring responsibilities via charity works or local communal life. This expectation about traditional domestic responsibilities interlocked with candidates' ages in certain ways that in this study of female candidates younger than male incumbents, it stood out as a barrier for female candidacy: average voters tended to vote for over-middle-aged male incumbents. This has two reasons: They believed that the "old men are wiser" and that the old male incumbents as the main breadwinner could not find another job if they lost the election, whereas female candidates supposedly had male breadwinners. Surely, this was influenced by other factors too, including the long tradition of these offices with a "headman" and "council of elders," and male incumbency. Similarly, re-running incumbents took advantage of their seat's resources with already locally embedded economic and social relations. In short, male incumbency at neighborhood offices, similar to offices at grand scales (Schwindt-Bayer, 2005), was a barrier for new and especially female candidates. 
What would need to be changed to shift these dynamics for creating an equal ground for all candidates for neighborhood offices? Now relatively experienced with elections, most female candidates suggest certain institutional initiatives for a fairer election for all, measures that do not ask for any positive discrimination for women. These include: providing all candidates with transparent and equal financial and political support by municipalities and political parties; improving the rules about candidacy deadlines, ballot provision, and consecutive term limits; and preventing incumbents from abusing governmental resources for their own campaigns. Also, reforming the neighborhood offices into a formal governing unit with a budget and providing muhtars and/ or their staffs with at least minimum wage but no service fees is necessary to improve this office's status in politics and also to encourage only the candidates willing to work as public servants, rather than those seeking only for a job. Unfortunately, most of these suggestions are unlikely to happen soon or ever, as since the 2004 election, the government has been transferring most paperwork responsibilities of neighborhood offices to other state agencies but without re-defining these offices' status.

How about female candidates' own strategies in the face of these barriers? Overall, nearly all female candidates had certain gendered and local opportunities, but could not mobilize them efficiently. A missed opportunity was not campaigning about the advantages of working with a female muhtar due to, for instance, her better communication and work skills with neighbors and governmental officials and bureaucracies. Another useful step would be to collaborate more with other female candidates in their or other neighborhoods, rather than competing against each other and diverting the votes for women. Another taken for guaranteed resource was female candidates' own charity and support networks at local level. Most of these women leaned on their neighborly contacts with electorates sentimentally but were ignorant about or inexperienced with transforming these contacts into electoral networks. Only one woman - the only candidate who won the election at her first candidacy-had such networks; retired and then involved in a city-wide ethnicity-based organization, she formed one of her election campaign teams out of this organization's members living in her neighborhood. Meanwhile, female candidates' training by KA-DER, a woman's organization, focused on women's public appearances and speeches, rather than on campaign strategies that could be a major assistance to inexperienced candidates.

Some female candidates still did not recognize the importance of utilizing such gendered and local network-based assets of their own for their political success. Nearly all of them today put the blame for their loss on the "rules of the game (that are) unethical and dishonest," rightfully but similar to most women characterizing politics as "dirty" and as something that belongs to the men's world (Sancar-Usur, 2003). Of these rules, some of the informal ones were developed as frauds and are surely unethical. Some others are self-evolved tactics at a competition that developed on the ground with relatively weak formal rules. In addition to the changes about the electoral conditions for neighborhood offices, there is a need for female candidates to become familiar with experiences and tactics for and around the ballot box and to search for ways to mobilize their own resources and support-networks and/or develop new ones for their election campaigns.

\section{Acknowledgement}

I am grateful to all of the research participants who shared their stories with enthusiasm and honesty, the Eskisehir branch of KADER (Association for the Support and Training of Women Candidates) for leading me to these participants, and the insightful comments of three anonymous reviewers.

\section{References}

Abu-Lughod, Janet L. (1994). From urban village to east village. Oxford, UK; Cambridge, USA: Blackwell.

Ackelberg, Martha A. (1988). Communities, resistance, and women's activism. In A. Bookman, \& S. Morgen (Eds.), Women and the politics of empowerment (pp. 15-24). Philadelphia: Temple University Press.

Anker, R., Melkas, H., \& Korten, A. (2003). Gender-based occupational segregation in the 1990s. Working Paper 16, ILO. Available from. http://www.ilo.org/public/ english/standards/decl/declaration/text/index.htm (Accessed on 01.24.2007).

Arat, Y. (1989). The patriarchal paradox: Women politicians in Turkey. London: Associated University Presses.

Beall, Jo (2004). Decentralisation and engendering democracy. Working Paper 1. London: Crisis States Research Centre/London School of Economics.

Berry, Jeffrey M., Portney, K. E., \& Thompson, K. (1993). The rebirth of urban democracy. Washington, D.C.: Bookings Institution.

Bondi, L., \& Peake, L. (1988). Gender and the city. In J. Little, L. Peake, \& P. Richardson (Eds.), Gender and the urban environment. New York: New York University Press. Citci, O. (2001). Yerel secimler panaromasi: 1963-1999. Working Paper 265. Ankara: TODAIE.

Conover, P. J., Searing, D. D., \& Crewe, I. (1991). The nature of citizenship in the United States and Great Britain. Journal of Politics, 53/3, 800-832.

Etzioni, A. (1993). The spirit of community. New York: Touchstone Publication.

Evertzen, A. (2001). Gender and local governance. Amsterdam: Netherlands Development Organization.

Faguet, Jean P. (2004). Does decentralization increase government responsiveness to local needs? Journal of Public Economics, 88, 867-893.

Fisher, R., \& Kling, J. (Eds.). (1993). Mobilizing the community. Newbury Park: Sage Publications.

Frey, F. W. (1965). The Turkish political elite. Massachusets: MIT Press.

Real Utopias Project 4. In Fung, A., \& Wright, E. O. (Eds.), Deepening democracy: Institutional innovations in empowered participatory governance. London: Verso.

Gunes-Ayata, A. (1991). Women's participation in politics in Turkey. In S. Tekeli (Ed.), Women in modern Turkish society. Istanbul: Iletisim Yayinlari.

Gunes-Ayata, A., \& Tutuncu, F. (2008). Critical acts without a critical mass. Parliamentary Affairs, 61/3, 461-475.

Hill Collins, P. (1990). Black feminist thought. New York: Routledge.

Incioglu, N. (2002). Local elections and electoral behavior. In S. Sayarı, \& Y. Esmer (Eds.), Politics, parties and elections in Turkey (pp. 73-101). Boulder: Lynne Riener Publishers.

IPU. (2008). Inter-parliamentary union. Available from. http://www.ipu.org/wmn-e/ world-arc.htm (Accessed on: 09.15.2008).

Kandiyoti, D. (1991). Women, Islam and the state. Middle East Report, 173, 9-14.

Kandiyoti, D. (1987). Emancipated but unliberated? Feminist Studies, 13/2, 317-338.

Kearns, A. (1995). Active citizenship and local governance. Political Geography, 14/2, $155-175$.

Kemmis, D. (1995). Community and the politics of place. Norman: University of Oklahoma Press.

Lamphere, L. (Ed.). (1992). Structuring diversity. Chicago: University of Chicago Press. Lister, R. (1997). Citizenship: Feminist perspectives. London: Macmillan.

Lovenduski, J. (2001). Women and politics. Parliamentary Affairs, 54, 743-758.

McEwan, C. (2000). Engendering citizenship: gendered spaces of democracy in South Africa. Political Geography, 19, 627-651.

Manor, J. (1999). The political economy of democratic decentralization. Washington, D.C: World Bank.

Mansbridge, J. (1985). Beyond adversary democracy. Chicago: University of Chicago Press.

Marston, S. A. (1990). Who are the 'people'? Environment and Planning D: Society and Space, 8, 449-458.

Marston, S. A., \& Staeheli, L. A. (1994). Citizenship, struggle, and political and economic restructuring. Environment and Planning A, 26, 840-848.

Massey, D. (1994). Space, place, and gender. Minneapolis: University of Minnesota Press.

Matland, R. E. (1998). Women's representation in national legislatures. Legislative Studies Quarterly, 23/1, 109-125.

Milroy, B. M., \& Wismer, S. (1994). Communities, work and public/private sphere models. Gender, Place and Culture, 1/1, 71-90.

Naples, N. A. (Ed.). (1998). Community activism and feminist politics. London: Routledge.

Niven, D. (1998). The missing majority. Westport: Praeger.

Norris, P., \& Inglehart, R. (2000). Cultural barriers to women's leadership. Boston: IPSA.

Norris, P., \& Lovenduski, J. (1993). Gender and party politics in Britain. In J. Lovenduski, \& P. Norris (Eds.), Gender and party politics (pp. 35-59). London: Sage Publications.

OGU-Tekam. (2004). Eskişehir'de kadın profili raporu. Eskisehir: Osmangazi Universitesi. Available from. http://estekam.sitemynet.com/yazilar/19.htm (Accessed on: 10.20 .2008$)$.

Oncu, A. (1995). Turkish women in the profession. In S. Tekeli (Ed.), Women in modern Turkish society (pp. 181-193). London: Zed Books. 
Peake, L. J. (1995). Toward an understanding of the interconnectedness of women's lives. Urban Geography, 16/5, 414-439.

Phillips, A. (1995). The politics of presence. New York: Clarendon Press.

Pred, A. (1984). Place as historically contingent process. Annals of the Association of American Geographers, 74/2, 279-297.

Pulido, L. (1997). Community, place, and identity. In P. John, Jones, III, J. Heidi, Nast., \& S. M. Robert (Eds.), Thresholds in feminist geography. New York: Rowman \& Littlefield Publication.

Randall, V. (1987). Women and politics. Chicago: University of Chicago Press.

Rule, W. (1987). Electoral systems, contextual factors and women's opportunity for election to parliament in 23 democracies. Western Political Quarterly, 40/3, 477-498.

Sancar-Usur, S. (2003). Women in state, politics and civil society. In Bridging the Gender Gap in Turkey. World Bank Report /Europe and Central Asia Region, pp.167-180.

Sayarı, Sabri, \& Esmer, Y. (Eds.). (2002). Politics, parties and elections in Turkey. Boulder: Lynne Riener Publishers.

Schwindt-Bayer, L. A. (2005). The incumbency disadvantage and women's election to legislative office. Electoral Studies, 24, 227-244.

Secor, A. J. (2004). Feminizing electoral geography. In L. A. Staeheli, E. Kofman, \& L. J. Peake (Eds.), Mapping women, making politics (pp. 261-272). New York/ London: Routledge.

Secor, Anna J. (2001). Toward a feminist counter-geopolitics: gender, space and Islamist politics in Istanbul. Space E' Polity, 5/3, 191-211.
Staeheli, L. A., Kofman, E., \& Peake, L. J. (Eds.). (2004). Mapping women, making politics. New York/London: Routledge.

Staeheli, L. A. (1996). Publicity, privacy, and women's political action. Environment and Planning D: Society and Space, 14, 601-619.

Staeheli, L. A., \& Clarke, S. E. (1995). Gender, place, and citizenship. In A. JudithGarber, \& R. S. Turner (Eds.), Gender in urban research (pp. 3-23). Thousand Oaks: Sage Publications.

Studlar, D. T., \& Mcallister, I. (1991). Political recruitment to the Australian legislature. Western Political Quarterly 44/, 2, 467-485.

Tekeli, Sirin (Ed.). (1995). Women in modern Turkish society. London: Zed Books.

UNDP. (2006). Human development indicators. Available from. New York: UNDP. http://hdr.undp.org/hdr2006/statistics/countries/country_fact_sheets/cty_fs TUR.html (Accessed on: 09.08.2008).

Verba, S. (1990). Women in American politics. In L. A. Tilly, \& P. Gurin (Eds.), Women, politics, and change. New York: Russell Sage.

Verba, S., Schlozman, K. L., \& Brady, H. E. (1995). Voice and equality. Cambridge: Harvard University Press.

Walzer, M. (1983). Spheres of justice. New York: Basic Books.

Wolch, J. R., \& Dear, M. (Eds.). (1989). The Power of geography. Boston: Unwin Hyman.

World Bank. (2008). GenderStats: database of gender statistics. Available from. http://genderstats.worldbank.org/genderRpt.asp?rpt=profile\&cty=WLD, World\&hm=home (Accessed on: 01.25.2008).

Yaraman, A. (1999). Turkiye'de kadinlarin siyasal temsili (1935-1999). Istanbul: Baglam Yayinlari. 